\title{
Conception rate following timed artificial insemination protocols in dairy heifers synchronised by $\mathrm{PGF}_{2 \alpha}$ and $\mathrm{GnRH}$
}

\author{
Umut TAȘDEMİR ${ }^{1}$, Gülnaz YILMAZBAŞ-MECITOĞLU ${ }^{2}$, Abdulkadir KESKİN², \\ Ebru KARAKAYA ${ }^{2}$, Yakup ÇELIK ${ }^{3}$, Aydın GÜZELOĞLU ${ }^{4}$, Ahmet GÜMEN ${ }^{2}$ \\ ${ }^{1}$ Lalahan Livestock Central Research Institute, Lalahan, Ankara; ${ }^{2}$ Department of Obstetrics and Gynecology, Faculty of Veterinary \\ Medicine, University of Uludag, Bursa; ${ }^{3}$ TARFAS Co., Bursa; ${ }^{4}$ Department of Obstetrics and Gynecology, Faculty of Veterinary \\ Medicine, University of Selcuk, Konya, Turkey.
}

\begin{abstract}
Summary: This study aimed to develop a timed artificial insemination (TAI) protocol using PGF $2 \alpha$ and GnRH with acceptable pregnancy rate in dairy heifers. Dairy heifers ( $\mathrm{n}=290)$, aged between 13 and 26 months (mean 16.1 months), were used in this study. Heifers were synchronized with two $\mathrm{PGF}_{2 \alpha}$ administrations by $14 \mathrm{~d}$ intervals. After the second $\mathrm{PGF}_{2 \alpha}$, heifers were randomly assigned into two groups. In Group $1(\mathrm{n}=155)$, GnRH was given at $56 \mathrm{~h}$ following $2^{\text {nd }} \mathrm{PGF}_{2 \alpha}$ and TAI was performed at $16-$ $18 \mathrm{~h}$ after the GnRH. In Group 2 ( $\mathrm{n}=135)$, GnRH was administered at $72 \mathrm{~h}$ after $2^{\text {nd }} \mathrm{PGF}_{2 \alpha}$, at the time of TAI. Ultrasonography was performed at both $\mathrm{PGF}_{2 \alpha}$ administrations to determine cyclicity, at the time of TAI to measure ovulatory follicle size, $7 \mathrm{~d}$ after TAI to determine ovulation, 31 and $62 \mathrm{~d}$ post-AI to determine pregnancy. Ovulatory follicle size at the time of TAI was not significantly different between groups (12.8 $\pm 1.6 \mathrm{~mm}$ and $13.2 \pm 1.8 \mathrm{~mm}$ in group 1 and 2, respectively). Synchronization rate was similar in group $1(85.2 \% ; 132 / 155)$ and in group $2(91.1 \% ; 123 / 135)$. Conception rate $(\mathrm{CR})$ at $31 \mathrm{~d}$ was not different in group $1(59.8 \% ; 79 / 132)$ and in group $2(55.3 \% ; 68 / 123)$. Embryonic loss $(7.6 \% ; 6 / 79$ and $7.4 \% ; 5 / 68$ in group 1 and 2 respectively) was not different. Gender ratio of the calves was found different between groups. Proportion of the female calves born were higher $(\mathrm{P}=0.03)$ in group $1(63.3 \%$; $38 / 60)$ than in group $2(42.0 \% ; 21 / 50)$. In conclusion, both protocols can be used in order to eliminate estrous detection in large dairy herds. Although GnRH administration at the time of TAI was found to be useful to reduce handling of heifers, GnRH can be applied 16-18 $\mathrm{h}$ before AI to achive higher female calves ratio in large dairy farms.
\end{abstract}

Keywords: Dairy heifers, GnRH, $\mathrm{PGF}_{2 \alpha}$, timed artificial insemination, synchronization.

\section{PGF $_{2 a}$ ve GnRH Kullanılarak Senkronize Edilen Düvelerde Zaman Ayarlı SuniTohumlama Sonrasmda Elde Edilen Gebelik Oranları}

Özet: $\mathrm{Bu}$ çalışmanın amacı GnRH ve $\mathrm{PGF}_{2 \alpha}$ kullanılarak senkronize edilen düvelerde, östrüs kontrolleri yapılmadan uygulanan zaman ayarlı suni tohumlama sonrasında istenilen düzeyde gebelik oranı elde etmekti. Çalışmada yaşları 13 ile 24 ay arasında değişen (ortalama 16.1) düveler ( $\mathrm{n}=290)$ kullanıldı. Düveler 14 gün ara ile uygulanan $\mathrm{PGF}_{2 \alpha}$ ile senkronize edildi ve ikinci $\mathrm{PGF}_{2 \alpha}$ uygulaması sonras1 rastgele iki gruba ayrıld1. Grup l'e $(\mathrm{n}=155)$ ikinci $\mathrm{PGF}_{2 \alpha}$ uygulamasını takiben 56. saat $\mathrm{GnRH}$ ve $\mathrm{GnRH}$ uygulamasını taiben 16-18. saat zaman ayarlı suni tohumlama yapıldı. Grup 2'ye ise (n=135) ikinci PGF $2 \alpha$ uygulamasını takiben 72. saatte suni tohumlama GnRH ile birlikte uygulandı. Ovaryumların siklik olup olmadığını belirlemek amacıyla her iki PGF $2 \alpha$ uygulaması sırasında, ovaryumlarda folliküllerin çapını belirmek amacıyla suni tohumlama ile eş zamanlı olarak, ovulasyon oranını belirlemek amacıyla suni tohumlamayı takiben 7. gün, gebelik oranını belirlemek amacıyla suni tohumlamayı takiben 31 ve 62 . günlerde ultrasonografi uygulaması yapıldı. Suni tohumlama ile eş zamanlı olarak belirlenen follikül çaplarında gruplar arasında

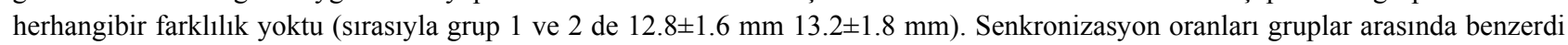
(\%85.2; 132/155 grup 1 ve $\% 91.1 ; 123 / 135$ grup 2). 31. günde belirlenen gebelik oranları değerlendirildiğinde gruplar arasında farklılı yoktu (\% 59.8; 79/132 grup 1 ve \% 55.3; 68/123 grup 2). Embriyonik kayıp gruplar arasında farklı değildi (sırasıyla grup 1 ve 2 de $\% 7.6 ; 6 / 79, \% 7.4 ; 5 / 68)$. Gruplar arasında cinsiyet oranları farklı belirlendi. Dişi buzağı oranı grup 1 de (\%63.3; 38/60) grup 2'ye oranla $(\% 42.0 ; 21 / 50)$ daha yüksek bulundu $(\mathrm{P}<0.05)$. Sonuç olarak, her iki protokolünde senkronizasyon amaciyla büyük sürü popülasyonuna sahip kızgınlık kontrolleri yapılmayan süt sığırcılığı işletmelerinde uygulanabileceği görüldü. Suni tohumlama uygulaması ile eş zamanlı olarak yapılan GnRH uygulamasının işletmede işçiliği azaltmasına rağmen, GnRH uygulamasının 16-18 saat önce yapılmasının dişi buză̆ı oranını arttırdığı belirlendi.

Anahtar kelimeler: Düve, GnRH, $\mathrm{PGF}_{2 \alpha}$, senkronizasyon, suni tohumlama 


\section{Introduction}

The most commonly used reproductive protocol for dairy heifers is insemination on detection of spontaneously displayed estrus $(22,23)$. Conception rate of synchronized heifers to the TAI are lower than heifers that are detected in estrus (38). Misdiagnosis of estrous detection in particularly large dairy herds leads to extended interval to pregnancy $(2,6,18)$. Many synchronization programs have been developed for estrus synchronization in cows and heifers $(7,11)$. Although estrous synchronization protocols aggregate estrous behaviours in cattle, daily observations is still needed to inseminate $(1,23)$.

Protocols using only $\mathrm{PGF}_{2 \alpha}$ for dairy heifers have resulted better reproductive efficiancy and economic outcomes, probably in herd with low estrus detection rate (15). Similar pregnancy outcomes have been reported for dairy heifers when two injections of $\mathrm{PGF}_{2 \alpha}$ and the Selectsynch were applied (33). Additionally, GnRH$\mathrm{PGF}_{2 \alpha}$ based protocols have been commonly used effectively in synchronizing estrus and ovulation (12, 35). Presynchronization before initiation of the GnRH$\mathrm{PGF}_{2 \alpha}$ protocol may be more effective to improve synchronization of follicular waves in heifers $(4,10)$.

Protocols using combinations of GnRH, $\mathrm{PGF}_{2 \alpha}$ and progesterone for beef heifers have not given successful results $(1,17)$. Previous studies have shown that most of the progesterone based estrous synchronization programs were associated with a reduction in conception rate $(16$, 37). Low serum progesterone concentration has resulted in development of large persistent follicle due to overstimulation with LH (29) and breeding these persistent follicles produces low fertility, which is probably associated with low progesterone concentrations (8).

Ovsynch protocols have been developed to synchronize ovulation in lactating dairy cows using GnRH and $\mathrm{PGF}_{2 \alpha}$ (22). This precise synchrony achieves an AI without the detection of estrus $(22,24)$. Unfortunately, mentioned TAI protocols have resulted in low fertility in heifers as satisfactory as in lactating cows (24). Ovsynch protocol synchronizes follicular and luteal development in lactating cows but not in heifers (26). The main reason for TAI failure in heifers in the Ovsynch seems to be due to differences in follicular dynamics, compared to cows $(10,12,30,34)$. Therefore, it is needed to develope new alternatives for optimum TAI programs in dairy heifers (28). Thus, the aims of this study were to develop TAI protocol in dairy heifers by using $\mathrm{PGF}_{2 \alpha}$ and $\mathrm{GnRH}$ and to compare two different TAI protocols in order to reduce handling in large dairy herds.

\section{Material and Method}

The study was carried out with 290 nulliparous Holstein Friesian heifers between January 2008 and
December 2009, aged between 13 and 26 months (mean 16.1 months), placed within a commercial farm in Bursa, Turkey. They were housed in a dirt lot with an indoor feeding area containing headlocks. Heifers received a mixed ration balanced to meet minimum nutritional requirments according to NRC (National Research Council 2001) and had free access to water. The experimental prosedures were approved by Lalahan Livestock Central Research Institute Animal Care Committe.

Heifers were synchronized with two $\mathrm{PGF}_{2 \alpha}(500 \mu \mathrm{g}$, im, cloprostenol sodyum; Juramate, Egevet, Turkey) administrations by $14 \mathrm{~d}$ intervals. After the second PGF $_{2 \alpha}$ heifers were randomly assigned into two groups. In group 1, GnRH (10 $\mu \mathrm{g}, \mathrm{im}$, Buserelin acetate, Receptal ${ }^{\circledR}$, Intervet, Turkey) was given at $56 \mathrm{~h}$ following $2^{\text {nd }} \mathrm{PGF}_{2 \alpha}$ and TAI was performed at $16-18 \mathrm{~h}$ after $\mathrm{GnRH}(\mathrm{n}=155)$. In group 2, GnRH was given at $72 \mathrm{~h}$ after $2^{\text {nd }} \mathrm{PGF}_{2 \alpha}$ at the time of TAI $(n=135)$.

Ultrasonographic examinations were done at beginning with first $\mathrm{PGF}_{2 \alpha}$ to determine the cyclicity of the heifers, at the time of second $\mathrm{PGF}_{2 \alpha}$ to detect corpus luteum $(\mathrm{CL})$ on the ovary, at the time of TAI to measure ovulatory follicle diameter, and 7 days after TAI to determine ovulation of the dominant follicle by using ultrasound machine with 7,5 MHz transducer (Honda HS 2000, Honda, Japan). Follicular diameter of the potentially ovulatory follicle(s) was obtained by averaging perpendicular measurements of the cross-sectional diameter for each follicle. Ovulatory response after GnRH was determined by absence of dominant follicle and presence of a new CL on the ovary 7 days after TAI. Early ovulation described as if there was no dominant follicle on the ovary at the time of TAI and presence of newly developed CL. If there was no CL on the ovary $7 \mathrm{~d}$ after AI, this condition described as no ovulation.

Pregnancy diagnosis was also performed with ultrasonography at 31 and at 62 days after TAI. Visualization of a fluid filled uterine horn with embryonic vesicles at $\mathrm{d} 31$ and the presence of a fetus at d 62 following TAI were used as a positive indications of pregnancy. The gender of the calves was recorded after calvings of the pregnant heifers. Synchronization rate was calculated as the number of heifers that responded to the GnRH, from the total number of all treated heifers. Conception rate was calculated as the number of heifers diagnosed pregnant at $\mathrm{d} 31$, divided by the number of heifers inseminated. The embryonic loss was calculated as the number of heifers diagnosed nonpregnant at $62 \mathrm{~d}$ post TAI, divided by the number of heifers diagnosed pregnant at 31 days post TAI. Gender ratio of the calves was calculated as the number of the male or female calves, divided by the number of the calves born.

Differences in follicular size between treatment groups were evaluated by student $t$ test. Synchronization 
Table 1: Dominant follicle size, synchronization rate, conception rate (d 31 and d 62), embryonic loss, and gender ratio was shown in dairy heifers

Tablo 1: Düvelerde follikül çapı, senkronizasyon oran1, gebelik oranı (31 ve 62. günler), embriyonik kayıp ve cinsiyet oranı

\begin{tabular}{|l|c|c|c|}
\hline & Group 1 & Group 2 & P value \\
\hline Dominant follicle size, synchronous TAI (mm) & $12.8 \pm 1.6$ & $13.2 \pm 1.8$ & 0.102 \\
\hline Syncronization rate (\%) & $132 / 155(85.2 \%)$ & $123 / 135(91.1 \%)$ & 0.121 \\
\hline Conception rate of d 31 & $79 / 132(59.8 \%)$ & $68 / 123(55.3 \%)$ & 0.461 \\
\hline Conception rate of d 62 (\%) & $73 / 132(55.3 \%)$ & $63 / 123(51.2 \%)$ & 0.514 \\
\hline Embryonic loss (\%) & $6 / 79(7.6 \%)$ & $5 / 68(7.4 \%)$ & 0.956 \\
\hline Female calves (\%) & $38 / 60(63.3 \%)^{\mathrm{a}}$ & $21 / 50(42.0 \%)^{\mathrm{b}}$ & 0.030 \\
\hline Male calves (\%) & $22 / 60(36.7 \%)^{\mathrm{b}}$ & $29 / 50(58.0 \%)^{\mathrm{a}}$ & 0.030 \\
\hline
\end{tabular}

- : No significant difference $(\mathrm{P}>0.05)$

a,b: Different superscripts within the same column demonstrate significant differences $(\mathrm{P}<0.05)$

rate, conception rate, embryonic loss and gender ratio were evaluated by Chi-square.

\section{Results}

Total of 290 heifers were used in this study. Some heifers $(n=35)$ were excluded from the study due to early ovulation $(n=20)$ or no ovulation $(n=15)$, data from 132 heifers in group 1 and 123 heifers in group 2 were used for the analyses.

Follicle size at the time of the TAI was similar between groups $(12.8 \pm 1.6 \mathrm{~mm}$ and $13.2 \pm 1.8 \mathrm{~mm}$ diameters in group 1 and 2, respectively; Table 1). Synchronization rate was $85.2 \%(132 / 155)$ in group 1 and $91.1 \%(123 / 135)$ in group 2 and there was no difference between groups (Table 1). Conception rate (d 31) was similar between groups, 59.8\% (79/132) in group 1 and 55.3\% (68/123) in group 2 in synchronized heifers (Table 1). When all heifers (synchronized and nonsynchronized) evaluated, conception rate was $51 \%$ $(79 / 155)$ in group 1 and 50.4\% (68/135) in group 2. Embryonic loss rate was similar $7.6 \%(6 / 79)$ in group 1 and $7.4 \%(5 / 68)$ in group 2 (Table 1). Interestingly, more $(\mathrm{P}=0.03)$ female calves born in group $1(63.3 \%$; $38 / 60)$ than in group $2(42.0 \% ; 21 / 50$ Table 1$)$.

\section{Discussion and Conclusion}

Two different TAI protocols using $\mathrm{PGF}_{2 \alpha}$ and GnRH were compared to achieve better pregnancy rate by optimizing the time of $\mathrm{GnRH}$ administration after second $\mathrm{PGF}_{2 \alpha}$ in dairy heifers.

Dominant follicle size at ovulation in heifers has been $13.0 \pm 0.3 \mathrm{~mm} \mathrm{(36)}$ and $13.4 \pm 2.0 \mathrm{~mm} \mathrm{(25)} \mathrm{in} \mathrm{earlier}$ studies. Similarly, size of the dominant follicle at the time of AI was measured as $12.8 \pm 1.6 \mathrm{~mm}$ in group 1 and $13.2 \pm 1.8 \mathrm{~mm}$ in group 2. Using $\mathrm{GnRH}$ to induce ovulation in cows with follicles larger than $11 \mathrm{~mm}$ in size has resulted in the development of the normal sized CL and releasing normal amount of progesterone (20). Ovulatory capacity is dependent on both the amount of
LH release and size of the follicle (30). Vasconcelos et al (1999) suggested that conception rate after $\mathrm{PGF}_{2 \alpha}-\mathrm{GnRH}$ administration was increased when small dominant follicle presence on the ovary during middle (d 5-13), instead of earlier (d 1-4) or later (d 14-21) stage of the cycle.

Some authors suggested that conception rate was negatively affected when application intervals of $\mathrm{PGF}_{2 \alpha}$ and GnRH administration inducing LH surge were shortened $(24,25)$. Souza et al (2007) reported that treatment with $\mathrm{GnRH}$ at $56 \mathrm{~h}$ after $\mathrm{PGF}_{2 \alpha}$ is likely to reduce size of ovulatory follicle compared to Cosynch at $72 \mathrm{~h}$ (GnRH-d7- $\left.\mathrm{PGF}_{2 \alpha}-72 \mathrm{~h}-\mathrm{GnRH}+\mathrm{AI}\right)$. In the current study, time differences between $\mathrm{PGF}_{2 \alpha}$ to $\mathrm{GnRH}$ did not effect the dominant follicle size at the time of $\mathrm{Al}$ in dairy heifers. Follicle growth seems to be more rapid for heifers than lactating cows $(22,24)$. Two $\mathrm{PGF}_{2 \alpha}$ administrations, $14 \mathrm{~d}$ apart, seems to be a proper synchronization rate for luteal and follicular dynamics in dairy heifers. When two $\mathrm{PGF}_{2 \alpha}$ administration combined with GnRH either $56 \mathrm{~h}$ or $72 \mathrm{~h}$ after second $\mathrm{PGF}_{2 \alpha}$ ovulation time could be precisely synchronized in dairy heifers.

Synchronization rate for this study was higher than those of some reported study (72\%) in Cosynch-CIDR and $(68 \%)$ in Selectsynch-CDIR protocol (35). Synchronization rate was similiar $(85-91 \%)$ to some others $(3,9,17,26)$. Synchronization rate was ranged 43 to $60 \%$ of beef and dairy heifers without presynchronization (31).

In the present study, conception rate was not statistically different between groups. These results were higher than those of some studies (37 and 39\%) that use $\mathrm{PGF}_{2 \alpha}$ treatment and visual detection of estrus $(14,19)$. Conception rate for dairy heifers receving $\mathrm{Al}$ at standing estrus was reported to be $47 \%$ (7) and $74 \%$ (24). GnRH at $\mathrm{Al}$ following detection of estrus has not influenced conception rate between beef cows and heifers (21). Conception rate in this study was higher than most of the TAI protocols in dairy heifers and comparable to breeding after detection of estrus. 
The fact that application of AI in nulliparous heifers, early in relation to ovulation results in high proportion rate (53.8-58\%) of female calves in previous $(23,27)$ and present study, even though a previous study suggested to be expected less female gender ratio, approximately of $45.8 \%$ (14). In agremeent to this result, increasing the interval from TAI to ovulation in lactating cows has been reported to increase female ratio (24). Female gender rate obtained from this study was higher than that of mentioned studies above. Gutie'rrez-Ada'n et al have shown that greater proportion of female embryos was obtained from early in vitro fertilization (IVF) treatment $(62 \%)$ compared to the later IVF treatment (38\%). In a previous study, it has been speculated that the synchronization might have changed the reproductive tract environment in favour of the survival of sperm carrying the $\mathrm{X}$ chromosome or the survival of female embryos (5). In this study, tendency to give birth of female calves were higher in group $1(63.3 \% ; 38 / 60)$ than group $2(42.0 \% ; 21 / 50)$. In previous studies, synchronization protocols such as Cosynch, CIDR and GnRH- PGF $2 \alpha$, are tended to have more female calves $(5,38)$. In this study, interestingly, female gender ratio found more than all previous studies.

In conclusion, pregnancy rate obtained from this study was acceptable, even it was higher in comparison to many TAI protocols in dairy heifers. GnRH administration at the time of TAI was found to be useful to reduce handling of heifers, GnRH can also be applied 16-18 $\mathrm{h}$ before TAI to achieve higher female calves ratio in dairy herds.

\section{Acknowledgments}

The authors thank TARFAS Co. (Bursa, TURKEY) for the use of their herd and facilities. Support was also provided by the The Scientific and Technological Research Council of Turkey (TUBITAK) grant no. TOVAG 1070227.

\section{References}

1. Bader JF, Kojima FN, Schafer DJ, Stegner JE, Ellersieck MR, Smith MF, Patterson DJ (2005): A comparison of progestin-basedprotocols to synchronize ovulation and facilitate fixed-time artificial insemination in postpartum beef cows. J Anim Sci, 83, 136-43.

2. Brusveen DJ, Cunha AP, Silva CD, Cunha PM, Sterry RA, Silva EP, Guenther JN, Wiltbank MC (2008): Altering the time of the second gonadotropin-releasing hormone injection and artificial insemination (A I) during Ovsynch affects pregnancies per AI in lactating dairy cows. J Dairy Sci, 91, 1044-52.

3. Bucher A, Kasimanickam R, Hall JB, Dejarnette JM, Whittier WD, Kahn W, Xu Z (2009): Fixed-time Al pregnancy rate following insemination with frozen-thawed or fresh-extended semen in progesterone supplemented CO-Synch protocol in beef cows. Theriogenology, 71, $180-5$.
4. Busch DC, Wilson DJ, Schafer DJ, Leitman NR, Haden JK, Ellersieck MR, Smith MF, Patterson DJ (2007): Comparison of progestin-based estrus synchronization protocols before fixed-time artificial insemination on pregnancy rate in beef heifers. J Anim Sci, 85, 1933-9.

5. Clutton-Brock, TH, Iason GR (1986): Sex ratio variation in mammals. Q Rev Biol, 61, 339-74.

6. Dalton JC, Manzo R, Ahmadzadeh A, Shafii B, Price WJ, DeJarnette JM (2005): Short communication: Conception rates following detection of estrus and timed AI in dairy cows synchronized using GnRH and PGF2alpha. J Dairy Sci, 88, 4313-6.

7. Donovan GA, Bennett FL, Frederick SP (2003): Factors associated with first service conception rates in artificially inseminated nulliparous Holstein heifers. Theriogenology, 60, 67-75.

8. Fonseca FA, Britt JH, McDaniel BT, Wilk JC, Rakes AH (1983): Reproductive traits of Holstein and Jerseys. Effects of age, milk yield, and clinical abnormalities on involution of cervix and uterus, ovulation, estrous cycles, detection of estrus, conception rate, and days open. J Dairy Sci, 66, 1128-47.

9. Fricke PM, Guenther JN, Wiltbank MC (1998): Effect of decreasing the dose of GnRH used in a protocol for synchronization of ovulation and timed AI in lactating dairy cows. Theriogenology, 50, 1275-84.

10. Galvâo KN, Sâ Filho MF, Santos JE (2007): Reducing the interval from pre synchronization to initiation of timed artificial insemination improves fertility in dairy cows. $\mathrm{J}$ Dairy Sci, 9, 4212-8.

11. Gatius FL (2000): Short Synchronization System For Estrus Cycles in Dairy Heifers: A Preliminary Report. Theriogenology, 54,1185-90.

12. Geary TW, Downing ER, Bruemmer JE, Whittier JC (1998): Ovarian and estrous response of suckled beef cows to the select synch estrous synchronization protocol. J Anim Sci, 16, 1-5.

13. Gutie'rrez-Ada'n A, Pe'rez-Garnelo J, Garde JJ, Pe'rez-Guzman M, Pinatado B, De La Fuente J (1999): Relationship between sex ratio and time of insemination according to both time of ovulation and matiirational state of oocyte. Zygote, 7, 37-43.

14. Jordan ER, Schouten MJ, Quast JW, Belschner AP, Tomaszewski MA (2002): Comparison of two timed artificial insemination (TAI) protocols for management of first insemination postpartum. J Dairy Sci, 85, 1002-8.

15. Larson JE, Lamb GC, Stevenson JS, Johnson SK, Day ML, Geary TW, Kesler DJ, DeJarnette JM, Schrick FN, DiCostanzo A, Arseneau JD (2006). Synchronization of estrus in suckled beef cows for detected estrus and artificial insemination and timed artificial insemination using gonadotropin-releasing hormone, prostaglandin F2a, and progesterone. J Anim Sci, 84, 332-42.

16. Larson LL, Ball PJH (1992): Regulation of estrous cycles in dairy cattle: a review. Theriogenology, 38, 255-67.

17. Lucy MC, Billings HJ, Butler WR, Ehnis LR, Fields MJ, Kesler DJ, Kinders JE, Mattos RC, Short RE, Thatcher WW, Wettemann RP, Yelich JV, Hafs HD (2001): Efficacy of an intravaginal progesterone insert and an injection of $\mathrm{PGF}_{2 \alpha}$ for synchronizing estrus and 
shortening the interval to pregnancy in postpartum beef cows, peripubertal beef heifers and dairy heifers. J Anim Sci, 79, 982-95.

18. Melendez P, Gonzalez G, Aguilar E, Loera O, Risco C, Archbald LF (2006): Comparison of two estrussynchronization protocols and timed artificial insemination in dairy cattle. J Dairy Sci, 89, 4567-72.

19. Peeler ID, Nebel RL, Pearson RE, Swecker WS, Garcia A (2004): Pregnancy rates after timed AI of heifers following removal of intravaginal progesterone inserts. J Dairy Sci, 87, 2868-73.

20. Perry GA, Smith MF, Lucy MC, Green JA, Parks TE, MacNeil MD (2005): Relationship between follicle size at insemination and pregnancy success. Proc Natl Acad Sci USA, 102, 5268-73.

21. Perry GA, Smith MF, Patterson DJ (2002): Evaluation of a fixed-time artificial insemination protocol for postpartum suckled beef cows. J Anim Sci, 80, 3060-4.

22. Pursley JR, Mee MO, Wiltbank MC (1995): Synchronization of ovulation in dairy cows using $\mathrm{PGF}_{2 \alpha}$ and GnRH. Theriogenology, 44, 915-23.

23. Pursley JR, Silcox RW, Wiltbank MC (1998): Effect of time of artificial insemination on pregnancy rates, calving rates, pregnancy loss, and gender ratio after synchronization of ovulation in lactating dairy cows. J Dairy Sci, 81, 2139-44.

24. Pursley JR, Wiltbank MC, Stevenson JS, Ottobre JS, Garverick HA, Anderson LL (1997): Pregnancy rates per artificial insemination for cows and heifers inseminated at a synchronized ovulation or synchronized estrus. J Dairy Sci, 80, 295-300.

25. Rantala MH, Katila T, Taponen J (2009): Effect of time interval between prostaglandin F(2alpha] and GnRH treatments on occurrence of short estrous cycles in cyclic dairy heifers and cows. Theriogenology, 71, 930-8.

26. Rivera H, Lopez H, Fricke PM (2004): Fertility of holstein dairy heifers after synchronization of ovulation and timed AI or AI after removed tail chalk. J Dairy Sci, 87, 2051-61.

27. Rivera H, Lopez H, Fricke PM (2005): Use of intravaginal progesteronereleasing inserts in a synchronization protocol before timed AI and for synchronizing return to estrus in Holstein heifers. J Dairy Sci, 88, 957-8.

28. Rivera H, Sterry RA, Fricke PM (2006): Presynchronization with gonadotropin-releasing hormone does not improve fertility in Holstein heifers. J Dairy Sci, 89, 3810-16.

29. Sâ Filho OG, Vilela ER, Geary TW, Vasconcelos JL (2009): Strategies to improve fertility in postpartum multiparous Bos indicus cows submitted to a fixed-time insemination protocol with gonadotropin-releasing hormone and prostaglandin F2alpha.. J Anim Sci, 87, 2806-14.
30. Sartori R Fricke PM, Ferreira JC, Ginther OJ, Wiltbank MC (2001): Follicular deviation and acquisition of ovulatory capacity in bovine follicles. Biol Reprod, 65, 1403-09.

31. Schafer DJ, Busch DC, Smith MF, Patterson DJ (2006): Characterization of follicular dynamics, timing of estrus, and response to GnRH and $P G$ in replacement beef heifers after presynchronization with a 14-day CIDR. J Anim Sci, 84, (Suppl. 1): 49.

32. Souza AH, Gumen A, Silva EPB, Cunha AP, Guenther JN, Peto CM,Caraviello DZ and Wiltbank MC (2007): Supplementation with estradiol-17p before the last gonadotropin-releasing hormone injection of the ovsynch protocol in lactating dairy cows. J Dairy Sci, 90, 4623-34.

33. Stevenson JS, Smith JF, Hawkins DE (2000): Reproductive outcomes for dairy heifers treated with combinations of prostaglandin F2a, norgestomet, and gonadotropin-releasing hormone. J Dairy Sci, 83, 2008 15.

34. Thompson KE, Stevenson JS, Lamb GC, Grieger DM, Loest CA (1999): follicular, hormonal, and pregnancy responses of early postpartum suckled beef cows to GnRH, norgestomet, and $\mathrm{PGF}_{2 \alpha}$. J Anim Sci, 77, 1823-32.

35. Vasconcelos JLM, Silcox RW, Rosa GJM, Pursley JR, Wiltbank MC (1999): Synchronization rate, size of the ovulatory follicle, and pregnancy rate after synchronization of oviilation beginning on different days of the estrous cycle in lactating dairy cows. Theriogenology, 52, 1067-78.

36. Wolfenson D, Inbar G, Roth Z, Kaim M, Bloch A, Braw-Tal R (2004): Follicular dynamics and concentrations of steroids and gonadotropin in lactating cows and nulliparoits heifers. Theriogenology, 62, 104255.

37. Xu ZZ, Burton LJ, Macmillan KL (1996): Reproductive performance of lactating dairy cows following oestrus synchronisation with progesterone, oestradiol andprostaglandin. NZ Vet J, 44, 99-104.

38. Xu ZZ, Burton LJ (2000): Estrus synchronization of lactating dairy cows with GnRH, progesterone, and prostaglandin F2 alpha. J Dairy Sci, 83, 471-6.

Geliş tarihi: 18.10.2010 / Kabul tarihi: 04.11.2010

Address for correspondence:
DVM, PhD Umut Taşdemir,
Lalahan Livestock Central Research Institute,
06852 Lalahan, Ankara
e-mail: tasdemiru@gmail.com

Address for correspondence:

Lalahan Livestock Central Research Institute,

e-mail: tasdemiru@gmail.com 